\title{
Tuning the solubilities of bis- triazinylphenanthroline ligands (BTPhens) and their complexes
}

Article

Accepted Version

Laventine, D. M., Afsar, A., Hudson, M. J. and Harwood, L. M. (2012) Tuning the solubilities of bis-triazinylphenanthroline ligands (BTPhens) and their complexes. Heterocycles. ISSN 1881-0942 doi: https://doi.org/10.3987/COM-12-S(N)102 Available at https://centaur.reading.ac.uk/29466/

It is advisable to refer to the publisher's version if you intend to cite from the work. See Guidance on citing.

To link to this article DOI: http://dx.doi.org/10.3987/COM-12-S(N)102

Publisher: The Japan Institute of Heterocyclic Chemistry

All outputs in CentAUR are protected by Intellectual Property Rights law, including copyright law. Copyright and IPR is retained by the creators or other copyright holders. Terms and conditions for use of this material are defined in the End User Agreement.

www.reading.ac.uk/centaur 
Central Archive at the University of Reading

Reading's research outputs online 
HETEROCYCLES, Vol. 86, No. 2, 2012, pp. -. () 2012 The Japan Institute of Heterocyclic Chemistry Received, 24th July, 2012, Accepted, 20th September, 2012, Published online, DOI: $10.3987 / C O M-12-S(N) 102$

\title{
TUNING THE SOLUBILITIES OF BIS-TRIAZINYLPHENANTHROLINE LIGANDS (BTPHENS) AND THEIR COMPLEXES
}

\section{Dominic M. Laventine, Ashfaq Afsar, Michael J. Hudson, and Laurence M. Harwood*}

Department of Chemistry, University of Reading, Whiteknights, Reading RG6 6AD, UK. E-mail: L.M.Harwood@reading.ac.uk

\begin{abstract}
A series of bis-triazinylphenanthroline ligands (BTPhens) was synthesized by modifying the triazine substituents. It was found that varying these substituents altered the solubilities of the ligands in a number of non-polar solvents. Thus C5-BTPhen showed significantly higher solubility in octanol than C1-BTPhen. The high solubility of C5-BTPhen and its complexes was exploited to facilitate the NMR titration experiments. These experiments shown that the dominant species in solution were the 1:2 complexes [Ln(III)(BTPhen) $)_{2}$, even at high Ln concentrations, and that the relative stability of the 2:1 to 1:1 BTPhen-Ln complexes varied with different lanthanides. C5-BTPhen therefore shows considerable promise for a once-through selective actinide separation process.
\end{abstract}

\section{INTRODUCTION}

Heterocyclic molecules are likely to be the principal molecules in some future separation processes in the nuclear fuel cycle. Currently, the separation of minor actinides(III) from lanthanides(III) is still receiving much attention. This separation of actinides(III) from lanthanides(III) is particularly difficult owing to the chemical similarities between the two groups of elements. ${ }^{1}$ However, it is thought that the greater availability of the valence orbitals in the actinides means that there is a more covalent contribution to metal-ligand bonding than with the lanthanides. ${ }^{2}$ It has been shown that 1,2,4 tridentate $N$-donor ligands can exploit this small but significant difference between the actinides and lanthanides. ${ }^{2}$ However, in addition to forming complexes selectively with actinides(III) rather than lanthanides(III), the ligands must have a sufficiently high solubility in the non-polar organic diluents that are used in the nuclear industry, 
such as TPH (similar to dodecane) and octanol. Typically the reprocessing is carried out in $3 \mathrm{M}$ nitric acid under (sometimes intense) irradiation and consequently molecules must show acceptable resistance towards both acidic hydrolysis and radiolysis, and any degradation products that form must not interfere with the extraction. It is also desirable that the ligand be composed of only carbon, hydrogen, oxygen and nitrogen (CHON principle) so that the ligand or its degradation products can be completely incinerated at the end of its useful life, thereby avoiding secondary waste generation. The development of $N$-heterocyclic ligands which are capable of fulfilling all these criteria has thus been the subject of intense research, which has recently been reviewed. ${ }^{1,2}$

Two classes of 1,2,4-triazines emerging from previous research are the (2,6-bistriazinyl)pyridines (BTP, 1) ${ }^{3}$ and the 6,6-bistriazinyl-2,2-bipyridines (BTBP, 2). ${ }^{4}$ CyMe4-BTBP is currently the benchmark molecules for the SANEX ( Selective Actinide Extraction) process. Experience with BTP and BTBP ligands has shown that it is beneficial to reduce the number of atoms in the ligand to achieve faster kinetics of extraction; whereas long aliphatic groups can provide the required solubility. The CyMe4 group has been found to be resistant to radiolysis, and provides a compromise between acceptable solubility and sufficiently high kinetics. There is a current view that molecules may be used in once-through processes and so resistance to radiolysis becomes less of a key feature in the design of the molecules. We have developed a class of ligands that replace the bipyridine skeleton with a 1,10-bisphenanthroline analogue (BTPhen, e.g. 3). By tethering the pyridine rings in this way, the molecule is held in the cis-conformation, removing the requirement for a conformational rearrangement prior to complexation. ${ }^{5}$ In addition, phenanthrolines have larger dipole moments than the 2,2'-bipyridines, ${ }^{6}$ and are known to coordinate strongly to water via hydrogen bonding, ${ }^{7}$ suggesting that they would interact more favourably with the organic/water interface. These changes have improved the kinetics of extraction compared to the corresponding BTBP while maintaining the high selectivity.<smiles>[R]c1nnc(-c2cccc(-c3nnc([R])c([R])n3)n2)nc1[R]</smiles>

1, R-BTP

$\mathrm{R}=\mathrm{Me}, \mathrm{Et}, \mathrm{Pr}, \mathrm{Bu}, \mathrm{Pent}$ Hex, CyMe4, Ar, etc

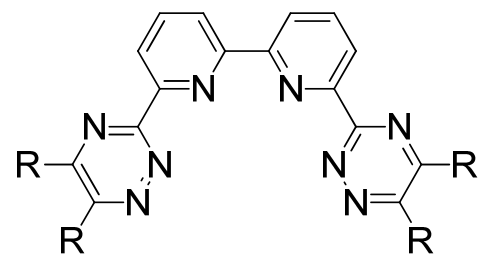

2, R-BTBP $\mathrm{R}=\mathrm{Me}, \mathrm{Et}, \mathrm{Bu}$, Pent, Hex, CyMe4, etc.

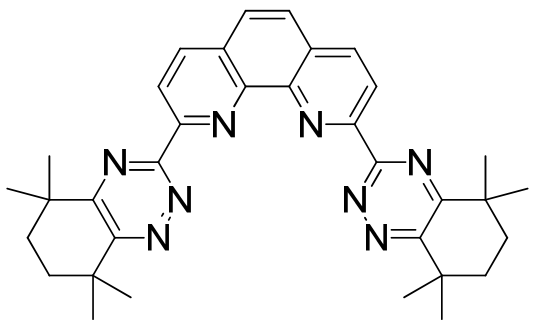

3, CyMe4-BTPhen

To date, CyMe4-BTPhen 3 is the only reported example of this class of ligand. Herein, we describe the 
synthesis of a number of examples of the BTPhen class of ligands with a variety of alkyl and aryl substituents on the triazine rings. Such modification can be simply achieved in the final step of the synthesis, allowing the solubilities of the ligands to be fine-tuned and solution phase characterization to be undertaken. A variety of substituents (including branched and cyclic aliphatic groups and aromatic groups) was chosen, in order to increase our understanding of the effect of substituent size on solubility and kinetics of extraction.

\section{RESULTS AND DISCUSSION}

The substituted BTPhen ligands were synthesized as shown in Scheme 1. The key intermediate, dihydrazide 8 was prepared from 2,9-dimethyl-1,10-phenanthroline 4 through a modification of our previously reported procedures. As in our previously reported method, dioxime 6 was produced by treatment of dialdehyde 5 with hydroxylamine hydrochloride, however, this intermediate was then isolated, and elimination achieved by treatment with $p$-toluenesulfonyl chloride and pyridine to afford the dinitrile 7. The reaction of the dinitrile 7 with hydrazine hydrate in $\mathrm{EtOH}$ gave the diamide dihydrazide 8 in near quantitative yield (40\% overall from neocuproine 4).
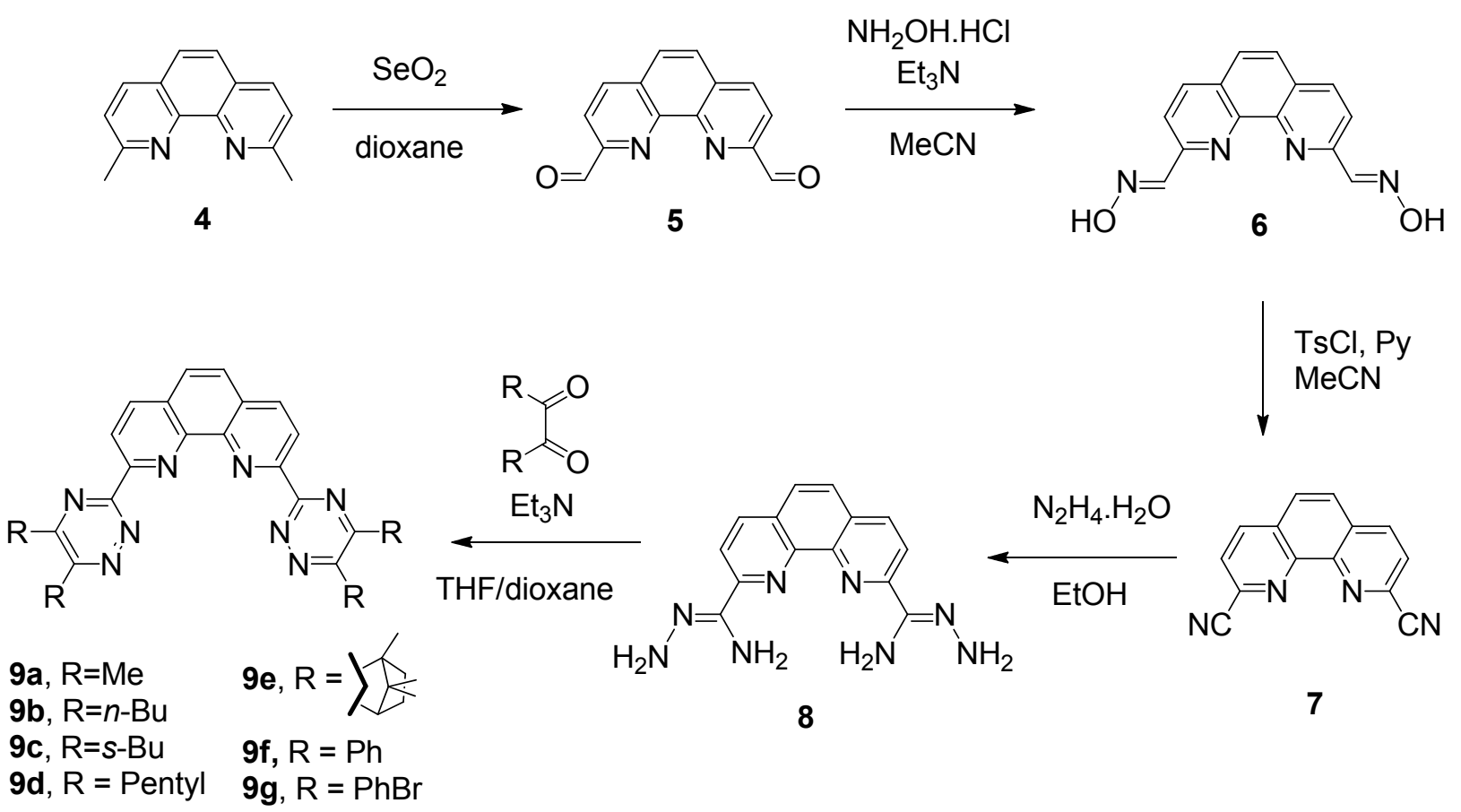

Scheme 1. Synthesis of BTPhens bearing alkyl and aryl side-chains.

The condensation of $\mathbf{8}$ was undertaken with commercially available and synthesized symmetrical 1,2-diketones. The synthesized diketones were produced by acyloin condensation ation of the appropriate ethyl ester followed by oxidation. The condensation reactions were performed in THF or dioxane, 
depending on the solubility of the diketone, under reflux in the presence of triethylamine $\left(\mathrm{Et}_{3} \mathrm{~N}\right)$. The novel 2,9-bis(1,2,4-triazin-3-yl)-1,10-phenanthroline ligands (BTPhens) 9a-g were obtained in moderate to good yields as a yellow-orange solids and their solubilities in various industrially relevant solvents were assessed (see Table 1).

Table 1. Yields and solubilities of BTPhens 9a-g.

\begin{tabular}{|c|c|c|c|c|c|c|}
\hline \multirow{2}{*}{ Cmpd. } & \multirow{2}{*}{$\mathrm{R}=$} & Subst. & Yield, & \multicolumn{3}{|c|}{ Solubility, mM } \\
\cline { 5 - 7 } & & type & $\%$ & $\mathrm{C}_{12} \mathrm{H}_{25}$ & $\mathrm{C}_{8} \mathrm{H}_{17} \mathrm{OH}$ & $\mathrm{C}_{6} \mathrm{H}_{10} \mathrm{O}$ \\
\hline 9a & $\mathrm{Me}$ & $\mathrm{C}_{\mathrm{Al}}$ & 79 & $\mathrm{x}$ & 3.0 & 0.007 \\
\hline 9b & $n-\mathrm{Bu}$ & $\mathrm{C}_{\mathrm{Al}}$ & 62 & 1.1 & 18.8 & 29.0 \\
\hline 9c & \multirow{2}{*}{$s-\mathrm{Bu}$} & $\mathrm{C}_{\mathrm{Al}, \mathrm{Br}}$ & 57 & 2.1 & 19.7 & 33.2 \\
\hline 9d & Pentyl & $\mathrm{C}_{\mathrm{Al}}$ & 35 & 2.5 & 21.4 & 33.5 \\
\hline 9e & $\mathrm{Camphor}$ & $\mathrm{C}_{\mathrm{Al}, \mathrm{Cy}}$ & 39 & 1.8 & 18.6 & 27.4 \\
\hline 9f & $\mathrm{Ph}$ & $\mathrm{C}_{\mathrm{Ar}}$ & 79 & $\mathrm{x}$ & 1.6 & 24.0 \\
\hline 9g & $\mathrm{PhBr}$ & $\mathrm{C}_{\mathrm{Ar}}$ & 61 & $\mathrm{x}$ & 2.1 & 15.0 \\
\hline
\end{tabular}

$\mathrm{Al}=\mathrm{Alkyl}, \mathrm{Br}=$ Branched, $\mathrm{Cy}=$ Cyclic, $\mathrm{Ar}=$ Aryl, $\mathrm{x}=$ insol.

The choice of diluents used in solvent extraction processes is constrained to those used in the nuclear industry. Solvents commonly include long chain hydrocarbons such as dodecane, alcohols such as octanol and cyclohexanone. ${ }^{8}$ The solubilities of the BTPhen ligands, in all solvents tested, increased as chain length was increased. These results bode well for the use of this class of ligands in solvent extractions.

The improved solubilities achieved also allowed solution characterization of the ligands and the complexes formed with metal salts. NMR titrations of the ligands with a number of lanthanides (La, Eu, $\mathrm{Lu})$ salts were performed in deuterated acetonitrile $\left(\mathrm{CD}_{3} \mathrm{CN}\right)$. Lanthanum (La) and Lutetium $(\mathrm{Lu})$ were chosen to give the greatest difference in atomic weight. Higher atomic weight lanthanides have been used as analogues for actinides in selective extractions from lower weight lanthanides. ${ }^{9,10}$ The results of the NMR titrations indicated that the ligands initially formed only 2:1 ligand-metal complexes in solution, as conversion to a single complex was complete after addition of 0.5 equivalents of metal salt for all lanthanides tested. Subsequent formation of 1:1 complexes was observed upon addition of excess metal salt (see Figures 1.1-2.2), although in all cases, the majority of the BTPhen remained bound in 2:1 complexes even at excess levels ( 3 equivalents) of $\mathrm{Ln}$. In the case of the lanthanum complex, formation of the $1: 1$ complex occurred to a greater degree for a given metal concentrations, compared to the 
corresponding lutetium complex. These results show that the relative thermodynamic stability of $2: 1$ complex compared to the $1: 1$ complex is greater for lutetium than for the lanthanum complexes. It has been postulated that the $2: 1$ complex is the actual extracting species owing to the metal center perhaps being completely enclosed by the hydrophobic shell formed by the two ligands. Hence the more relatively stable 2:1 complex would be more efficiently extracted, giving rise to the selectivity of solution phase extractions.

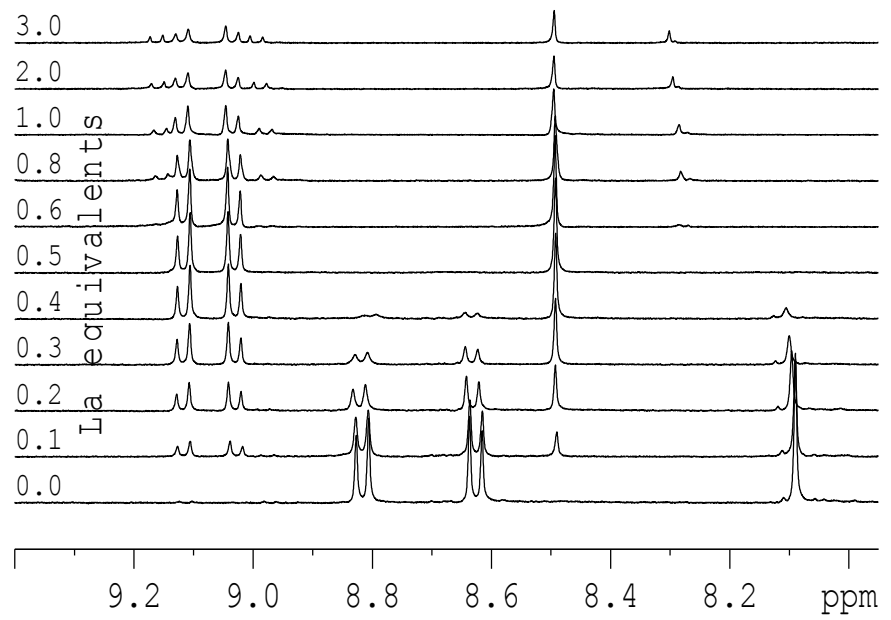

Figure 1.1. Stacked ${ }^{1} \mathrm{H}$ NMR spectra (8.0-9.3 ppm) of C5-BTPhen titrated with $\mathrm{La}\left(\mathrm{NO}_{3}\right)_{3} \cdot 6 \mathrm{H}_{2} \mathrm{O}$ in $\mathrm{CD}_{3} \mathrm{CN}$.

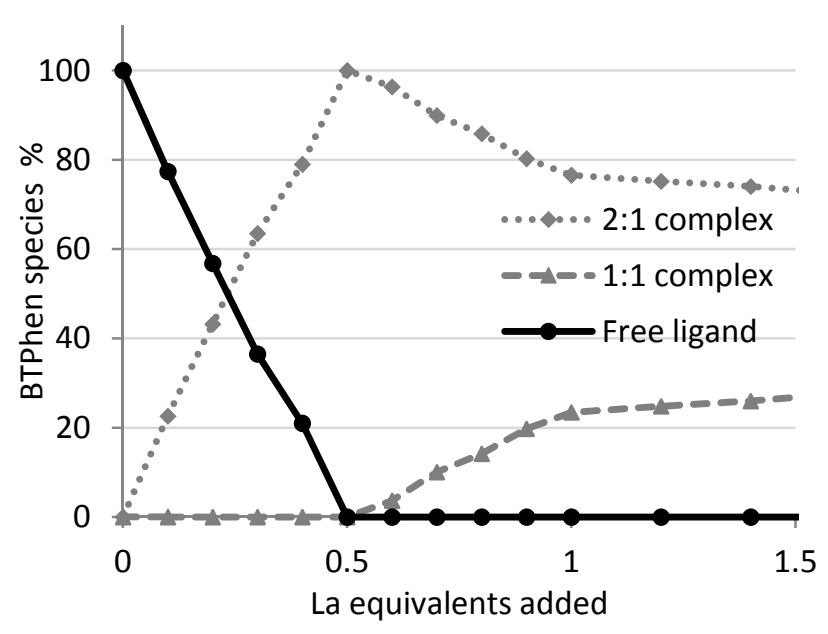

Figure 1.2. Graph showing C5-BTPhen composition at increasing La equivalents.

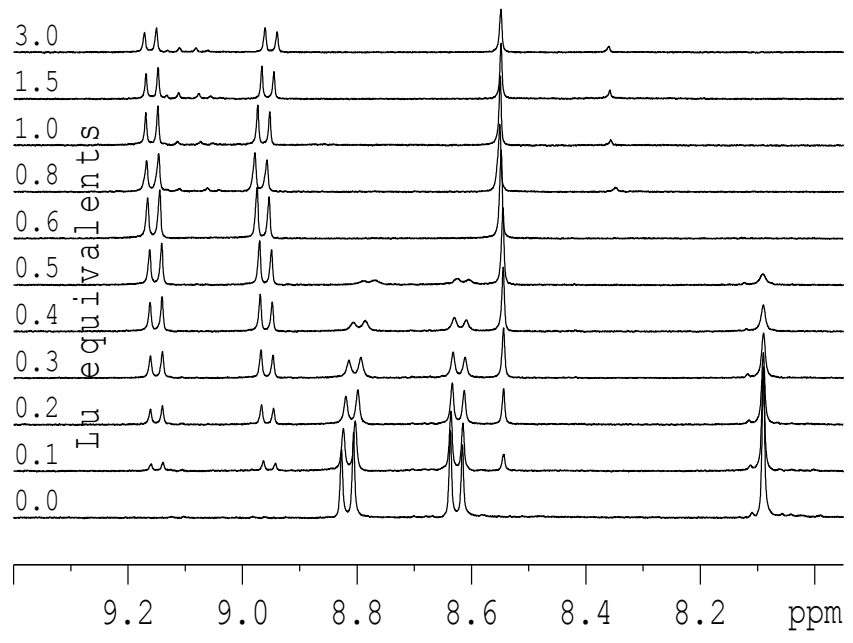

Figure 2.1. Stacked ${ }^{1} \mathrm{H}$ NMR spectra (8.0-9.3 ppm) of C5-BTPhen titrated with $\mathrm{Lu}\left(\mathrm{NO}_{3}\right)_{3}$ in $\mathrm{CD}_{3} \mathrm{CN}$.

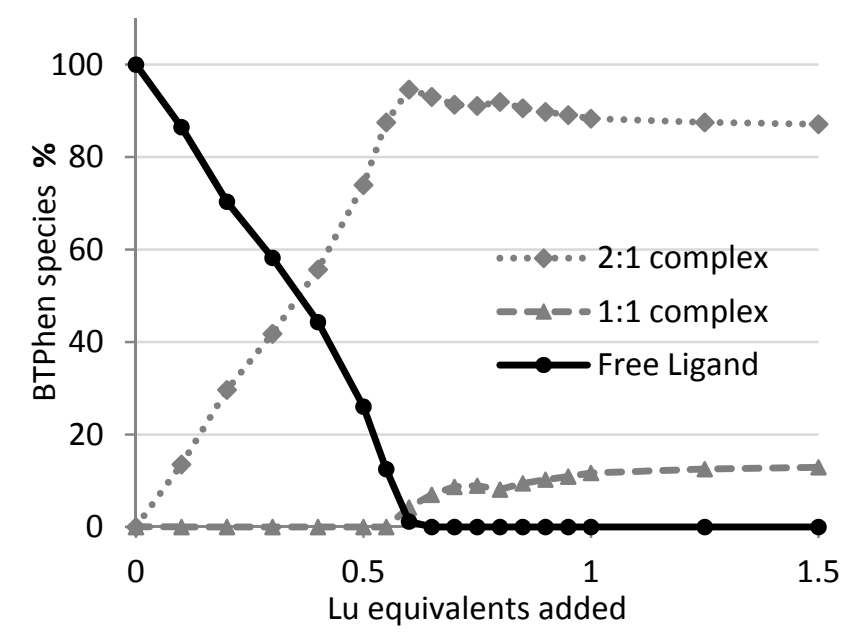

Figure 2.2. Graph showing $\mathrm{C} 5$-BTPhen composition at increasing $\mathrm{Lu}$ equivalents.

Assessment of these ligands partition coefficients and separation factors is currently being undertaken. Studies are also ongoing into the introduction of hydrophilic chains onto the triazine rings, producing novel water-soluble ligands that would allow reverse extraction or act as masking agents. 


\section{EXPERIMENTAL}

All reagents were either supplied by Acros, Aldrich, Fluka or Lancaster fine chemical suppliers, and were used as supplied. Diethyl ether $\left(\mathrm{Et}_{2} \mathrm{O}\right)$, toluene and tetrahydrofuran (THF) were dried by refluxing over and distillation from sodium benzophenone ketyl under nitrogen.

All ${ }^{1} \mathrm{H}$ and ${ }^{13} \mathrm{C}$ NMR spectra were recorded using either a Bruker AMX400 or an Avance DFX400 nstrument in $\mathrm{CDCl}_{3}$ or dimethyl sulfoxide- $d_{6}\left(\mathrm{DMSO}-d_{6}\right)$. Chemical shifts $(\delta)$ are reported in parts per million (ppm) with the abbreviations s, d, t, q, dd and br denoting singlet, doublet, triplet, quartet, double doublet and broad resonances respectively. Coupling constants $(J)$ are quoted in Hertz. IR spectra were recorded as Nujol ${ }^{\circledR}$ mulls (N) on a Perkin Elmer RX1 FT-IR instrument. Melting points were determined on a Gallenkamp melting point apparatus. Mass spectra $(\mathrm{m} / \mathrm{z})$ were recorded by electrospray ionisation(ESI) on an Xcalibur Tune $2.1(\mathrm{SP} 1)$ as $[\mathrm{MH}]^{+},[\mathrm{M}+\mathrm{Na}]^{+}$or $[2 \mathrm{M}+\mathrm{Na}]^{+}$.

\section{Synthesis of 1,10-Phenanthroline-2,9-dicarbaldehyde (5).}

Selenium dioxide (11.62 g, $104.7 \mathrm{mmol}, 2.1$ eq.) dissolved in dioxane (250 mL) and water $(\sim 7 \mathrm{~mL})$ was heated to reflux. To this solution was added a solution of 2,9-dimethyl-1,10-phenanthroline 4 (10.35 g, $49.7 \mathrm{mmol})$ in dioxane $(250 \mathrm{~mL})$ dropwise over $35 \mathrm{~min}$. The solution was heated under reflux for $30 \mathrm{~min}$. The reaction mixture was transferred while hot and allowed to cool overnight. The solid that separated was filtered and washed with $\mathrm{Et}_{2} \mathrm{O}(5 \times 50 \mathrm{~mL})$ and dried in a vacuum oven $\left(40{ }^{\circ} \mathrm{C}\right)$ to afford dialdehyde $\mathbf{5}$ as a pale brown solid $(10.92 \mathrm{~g}, 93 \%)$.

$\delta_{\mathrm{H}}\left(\mathrm{CDCl}_{3}\right)=8.05(\mathrm{~s}, 2 \mathrm{H}), 8.39(\mathrm{~d}, J=8.2 \mathrm{~Hz}, 2 \mathrm{H}), 8.52(\mathrm{~d}, J=8.2 \mathrm{~Hz}, 2 \mathrm{H}), 10.57(\mathrm{~s}, 2 \mathrm{H}) . \delta_{\mathrm{C}}$ $\left(\mathrm{DMSO}-d_{6}\right)=120.0,129.1,131.3,138.3,145.1,152.1,193.6 \mathrm{ppm} . \mathrm{C}_{14} \mathrm{H}_{8} \mathrm{~N}_{2} \mathrm{O}_{2}[\mathrm{M}+\mathrm{Na}]$ requires $m / z$ 259.0478; (FTMS + p ESI) MS found $m / z$ 259.0843; IR $v_{\max } / \mathrm{cm}^{-1}=3351,3159,1695(\mathrm{C}=\mathrm{O}), 1573,1491$, 1365.

\section{Synthesis of 1,10-Phenanthroline-2,9-dicarbonitrile (7)}

To a suspension of 1,10-phenanthroline-2,9-dicarbaldehyde 5 (14.02 g, $59.3 \mathrm{mmol})$ in dry MeCN (600 $\mathrm{mL}$ ) was added hydroxylamine hydrochloride $(8.94 \mathrm{~g}, 128.7 \mathrm{mmol}, 2.2 \mathrm{eq})$ and $\mathrm{Et}_{3} \mathrm{~N}(50 \mathrm{~mL}, 358.5 \mathrm{mmol}$, $6 \mathrm{eq})$. After heating the solution under reflux for $4 \mathrm{~h}$, the mixture was allowed to cool to room temperature. $p$-Toluenesulfonyl chloride $(35.99 \mathrm{~g}, 188.9 \mathrm{mmol}, 3.3 \mathrm{eq})$ and pyridine $(30 \mathrm{~mL}, 372.7 \mathrm{mmol}$, $6.3 \mathrm{eq}$ ) were added and the mixture was heated under reflux for $24 \mathrm{~h}$. The mixture was filtered while hot and the solid residue was washed with hot $\mathrm{MeCN}(50 \mathrm{~mL})$. The filtrate was evaporated to afford a brown semi-solid which was triturated with $\mathrm{MeOH}(200 \mathrm{~mL})$, then filtered and washed with $\mathrm{MeOH}(200 \mathrm{~mL})$ and $\mathrm{Et}_{2} \mathrm{O}(200 \mathrm{~mL})$ to afford 7 as a pale brown solid $(8.25 \mathrm{~g}, 60 \%)$.

$\delta_{\mathrm{H}}\left(\mathrm{DMSO}-d_{6}\right)=8.28(\mathrm{~s}, 2 \mathrm{H}), 8.41(\mathrm{~d}, J=8.2 \mathrm{~Hz}, 2 \mathrm{H}), 8.83(\mathrm{~d}, J=8.2 \mathrm{~Hz}, 2 \mathrm{H}) \mathrm{ppm} . \delta_{\mathrm{C}}\left(\mathrm{DMSO}-d_{6}\right)=$ 
117.6, 127.6, 129.2, 130.5, 132.9, 138.6, 144.8 ppm. $\mathrm{C}_{14} \mathrm{H}_{6} \mathrm{~N}_{4}[\mathrm{MH}]^{+}$requires $m / z$ 231.0665; (FTMS $+\mathrm{p}$ ESI) MS found $m / z$ 231.0661; IR $v_{\max } / \mathrm{cm}^{-1}=3086,3063,2238(\mathrm{C} \equiv \mathrm{N}), 1621,1500,1368$.

\section{Synthesis of 1,10-Phenanthroline-2,9-dicarbohydrazonamide (8)}

To a suspension of 1,10-phenanthroline-2,9-dicarbonitrile $7(4.17 \mathrm{~g}, 18.1 \mathrm{mmol})$ in EtOH $(250 \mathrm{~mL})$ was added hydrazine hydrate $(150 \mathrm{~mL}, 64 \%)$. The suspension was stirred at room temperature for 6 days. After concentrating the mixture under reduced pressure, $\mathrm{Et}_{2} \mathrm{O}(200 \mathrm{~mL})$ was added and the precipitated solid was filtered and allowed to dry in the air overnight to afford 8 as a brown solid (4.51 g, 85\%). $\delta_{\mathrm{H}}\left(\mathrm{DMSO}-d_{6}\right)=5.66($ br s, 4H), $6.12($ br s, 4H), $7.94(\mathrm{~s}, 2 \mathrm{H}), 8.28(\mathrm{~d}, J=8.5 \mathrm{~Hz}, 2 \mathrm{H}), 8.37(\mathrm{~d}, J=8.5$ $\mathrm{Hz}, 2 \mathrm{H}) \mathrm{ppm} . \delta_{\mathrm{C}}\left(\mathrm{DMSO}-d_{6}\right)=118.9,125.9,128.1,136,143.3,143.4,151.2 \mathrm{ppm} . \mathrm{C}_{14} \mathrm{H}_{14} \mathrm{~N}_{8}[\mathrm{MH}]^{+}$ requires $m / z$ 295.1414; (FTMS + p ESI) MS found $m / z$ 295.1412; IR $v_{\max } / \mathrm{cm}^{-1}=3326(\mathrm{~N}-\mathrm{H}), 3174(\mathrm{~N}-\mathrm{H})$, $3043(\mathrm{~N}-\mathrm{H}), 1619,1497,1128$.

\section{Synthesis of 2,9-Bis(dimethyl-1,2,4-triazin-3-yl)-1,10-phenanthroline (Me2-BTPhen, 9a)}

To a suspension of 1,10-phenanthroline-2,9-dicarbohydrazonamide 8 (0.95 g, $3.2 \mathrm{mmol})$ in THF (60 mL) was added 2,3-butanedione $(0.60 \mathrm{~mL}, 6.9 \mathrm{mmol}, 2.2 \mathrm{eq}) . \mathrm{Et}_{3} \mathrm{~N}(6 \mathrm{~mL}, 42.7 \mathrm{mmol})$ was added and the mixture was heated under reflux for $24 \mathrm{~h}$. After allowing the solution to cool to room temperature, the solvent was evaporated and the remaining solid residue was triturated with $\mathrm{Et}_{2} \mathrm{O}(20 \mathrm{~mL})$. The insoluble solid was filtered and washed with $\mathrm{MeOH}(10 \mathrm{~mL})$ and $\mathrm{Et}_{2} \mathrm{O}(20 \mathrm{~mL})$ and allowed to dry in a vacuum oven $\left(40{ }^{\circ} \mathrm{C}\right)$ to afford the ligand $9 \mathrm{a}$ as a pale brown solid $(1.02 \mathrm{~g}, 79 \%)$.

$\operatorname{mp} 218-221{ }^{\circ} \mathrm{C} ; \delta_{\mathrm{H}}\left(\mathrm{CDCl}_{3}\right)=2.74(\mathrm{~s}, 6 \mathrm{H}), 2.77(\mathrm{~s}, 6 \mathrm{H}), 8.16(\mathrm{~s}, 2 \mathrm{H}), 8.71(\mathrm{~d}, 2 \mathrm{H}), 8.71(\mathrm{~d}, 2 \mathrm{H}) . \delta_{\mathrm{C}}$ $\left(\mathrm{CDCl}_{3}\right)=19.3,21.7,122.3,127.7,129.4,137.9,144.6,151.7,157.6,160,160.2 \mathrm{ppm} . \mathrm{C}_{22} \mathrm{H}_{18} \mathrm{~N}_{8}[\mathrm{MH}]^{+}$ requires $m / z$ 395.1727; (FTMS + p ESI) MS found $m / z$ 395.1723; IR $v_{\max } / \mathrm{cm}^{-1}=3516,3407,3174,2985$ (C-H), 1626, 1528, 1497, 1449, 1394, 1371, 1166.

\section{Synthesis of 2,9-Bis(dimethyl-1,2,4-triazin-3-yl)-1,10-phenanthroline (n-C4-BTPhen, 9b)}

To a suspension of 1,10-phenanthroline-2,9-dicarbohydrazonamide 8 (1.00 g, $3.4 \mathrm{mmol})$ in THF (100 $\mathrm{mL}$ ) was added decane-5,6-dione (1.33 g, $7.8 \mathrm{mmol}, 2.3 \mathrm{eq}) . \mathrm{Et}_{3} \mathrm{~N}(6 \mathrm{~mL}, 42.6 \mathrm{mmol})$ was added and the mixture was heated under reflux for 3 days. The solution was allowed to cool to room temperature and filtered and the remaining solid residue was washed with DCM $(50 \mathrm{~mL})$. The filtrate was evaporated and the solid was triturated with ice-cold $\mathrm{Et}_{2} \mathrm{O}(200 \mathrm{~mL})$. The insoluble solid was filtered and washed with ice-cold $\mathrm{Et}_{2} \mathrm{O}(200 \mathrm{~mL})$ and allowed to dry in air to afford the ligand $\mathbf{9 b}$ as an orange solid $(0.61 \mathrm{~g}, 62 \%)$. $\mathrm{mp} 147-150{ }^{\circ} \mathrm{C} ; \delta_{\mathrm{H}}\left(\mathrm{CDCl}_{3}\right)=1.00(\mathrm{~m}, 12 \mathrm{H}), 1.55(\mathrm{~m}, 8 \mathrm{H}), 1.92(\mathrm{~m}, 8 \mathrm{H}), 3.13(\mathrm{~m}, 4 \mathrm{H}), 7.96(\mathrm{~s}, 2 \mathrm{H}), 8.49$ $(\mathrm{d}, J=8.4 \mathrm{~Hz}, 2 \mathrm{H}), 8.94(\mathrm{~d}, J=8.4 \mathrm{~Hz}) . \delta_{\mathrm{C}}\left(\mathrm{CDCl}_{3}\right)=13.9,22.6,22.9,30.4,30.6,32.2,33.9,123.1$, 
127.7, 130.0, 137.4, 146.6, 153.4, 160.1, 161.4, 162.7. $\mathrm{C}_{34} \mathrm{H}_{43} \mathrm{~N}_{8}[\mathrm{MH}]^{+}$requires $m / z$ 563.3611; (FTMS + p ESI) MS found $m / z$ 563.3616; IR $v_{\max } / \mathrm{cm}^{-1}=3511,2955(\mathrm{C}-\mathrm{H}), 2930(\mathrm{C}-\mathrm{H}), 2871(\mathrm{C}-\mathrm{H}), 2676,1621$, 1586, 1519, 1497, 1443, 1383.

\section{Synthesis of 2,9-Bis(dimethyl-1,2,4-triazin-3-yl)-1,10-phenanthroline (s-C4-BTPhen, 9c).}

To a suspension of 1,10-phenanthroline-2,9-dicarbohydrazonamide 8 (0.56 g, $1.9 \mathrm{mmol})$ in THF (50 mL) was added 3,6-dimethyloctane-4,5-dione (1.33 g, $7.8 \mathrm{mmol}, 2.3 \mathrm{eq})$. Et $3 \mathrm{~N}$ (1.5 mL, $10.7 \mathrm{mmol})$ was added and the mixture was heated under reflux for 7 days. The solution was allowed to cool to room temperature and filtered and the remaining solid residue was washed with DCM $(25 \mathrm{~mL})$. The filtrate was evaporated and the solid was triturated with $\mathrm{Et}_{2} \mathrm{O}(100 \mathrm{~mL})$. The insoluble solid was filtered and washed with $\mathrm{Et}_{2} \mathrm{O}(100 \mathrm{~mL})$ and allowed to dry in air to afford the ligand $9 \mathrm{c}$ as a brown solid $(0.241 \mathrm{~g}, 23 \%)$. NMR analysis indicated that $9 \mathbf{c}$ was obtained as a mixture of diastereoisomers.

$\mathrm{mp} 148-151{ }^{\circ} \mathrm{C} ; \delta_{\mathrm{H}}\left(\mathrm{CDCl}_{3}\right)=0.95(\mathrm{~m}, 12 \mathrm{H}), 1.46(\mathrm{~m}, 12 \mathrm{H}), 1.86(\mathrm{~m}, 4 \mathrm{H}), 2.1(\mathrm{~m}, 4 \mathrm{H}), 3.24(\mathrm{~m}, 4 \mathrm{H})$, $7.96(\mathrm{~m}, 2 \mathrm{H}), 8.48(\mathrm{~m}, 2 \mathrm{H}), 8.96(\mathrm{~m}, 2 \mathrm{H}) \mathrm{ppm} . \delta_{\mathrm{C}}\left(\mathrm{CDCl}_{3}\right)=12.2,12.4,19.4,20.5,28.7,29.5,36.8,37.7$, 122.7, 123.2, 126.6, 127.7, 129.6, 129.8, 137.4, 163.1, 165.3 ppm. $\mathrm{C}_{34} \mathrm{H}_{43} \mathrm{~N}_{8}[\mathrm{MH}]^{+}$requires $m / z$ 563.3611; (FTMS + p ESI) MS found $m / z$ 563.3612; IR $v_{\max } / \mathrm{cm}^{-1}=3361,2963(\mathrm{C}-\mathrm{H}), 2873(\mathrm{C}-\mathrm{H}), 1615$, $1495,1381$.

\section{Synthesis of 2,9-bis(5,6-dipentyl-1,2,4-triazin-3-yl)-1,10-phenanthroline (C5-BTPhen, 9d)}

To a suspension of 1,10-phenanthroline-2,9-dicarbohydrazonamide 8 (0.50 g, $1.7 \mathrm{mmol})$ in THF (50 mL) was added dodecane-6,7-dione (0.76 g, $3.8 \mathrm{mmol}, 2.2 \mathrm{eq}) . \mathrm{Et}_{3} \mathrm{~N}(3 \mathrm{~mL}, 21.3 \mathrm{mmol})$ was added and the mixture was heated under reflux for 3 days. . After allowing the solution to cool to room temperature, the solvent was evaporated and the remaining semi-solid residue was triturated with ice-cold $\mathrm{Et}_{2} \mathrm{O}(100 \mathrm{~mL})$. The insoluble solid was filtered and washed with ice-cold $\mathrm{Et}_{2} \mathrm{O}(100 \mathrm{~mL})$ and allowed to dry in air to afford the ligand $9 \mathrm{~d}$ as a yellow solid $(0.27 \mathrm{~g}, 35 \%)$.

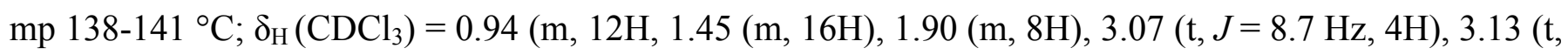
$J=8.7 \mathrm{~Hz}, 4 \mathrm{H}), 7.96(\mathrm{~s}, 2 \mathrm{H}), 8.45(\mathrm{~d}, J=8.3 \mathrm{~Hz}, 2 \mathrm{H}), 8.93(\mathrm{~d}, J=8.3 \mathrm{~Hz}, 2 \mathrm{H}) \mathrm{ppm} . \delta_{\mathrm{C}}\left(\mathrm{CDCl}_{3}\right)=14.0$, 14.1, 22.5, 22.5, 28.2, 28.3, 31.7, 32.1, 32.4, 34.4, 123.1, 127.5, 129.7, 137.2, 146.6, 153.6, 160.0, 161.6, 162.6. $\mathrm{C}_{76} \mathrm{H}_{100} \mathrm{~N}_{16}[\mathrm{M}+\mathrm{Na}]$ requires $\mathrm{m} / z$ 1259.8209; (FTMS + c ESI) MS found $\mathrm{m} / z$ 1259.8235; IR $v_{\max } / \mathrm{cm}^{-1}=3511,2956(\mathrm{C}-\mathrm{H}), 2926(\mathrm{C}-\mathrm{H}), 2858(\mathrm{C}-\mathrm{H}), 2674,2490,1622,1585,1518,1496$.

\section{Synthesis of 2,9-Bis(dimethyl-1,2,4-triazin-3-yl)-1,10-phenanthroline (Camphor-BTPhen, 9e)}

To a suspension of 1,10-phenanthroline-2,9-dicarbohydrazonamide 8 (0.98 g, $3.3 \mathrm{mmol})$ in THF (50 mL) was added camphor-quinone (1,21 g, $7.26 \mathrm{mmol}, 2.2 \mathrm{eq}) . \mathrm{Et}_{3} \mathrm{~N}(6 \mathrm{~mL}, 42.7 \mathrm{mmol})$ was added and the 
mixture was heated under reflux for $24 \mathrm{~h}$. After allowing the solution to cool to room temperature, the solvent was evaporated and the remaining solid residue was triturated with $\mathrm{Et}_{2} \mathrm{O}(20 \mathrm{~mL})$. After cooling to $0{ }^{\circ} \mathrm{C}$ in an ice-bath, the insoluble solid was filtered and washed with $\mathrm{Et}_{2} \mathrm{O}(20 \mathrm{~mL})$ and allowed to dry in a vacuum oven $\left(40{ }^{\circ} \mathrm{C}\right)$ to afford a mixture of three regioisomers of ligand $9 \mathbf{e}$ as a pale brown solid $(0.49 \mathrm{~g}$, $39 \%)$.

mp 208-213 ${ }^{\circ} \mathrm{C} ; \mathrm{C}_{22} \mathrm{H}_{18} \mathrm{~N}_{8}[\mathrm{MH}]^{+}$requires $m / z$ 395.1727; (FTMS + p ESI) MS found $m / z$ 395.1723; IR $v_{\max } / \mathrm{cm}^{-1}=3450,2960(\mathrm{C}-\mathrm{H}), 2875(\mathrm{C}-\mathrm{H}), 1754,1594,1520$.

\section{Synthesis of 2,9-Bis(diphenyl-1,2,4-triazin-3-yl)-1,10-phenanthroline (Ph2-BTPhen, 9f)}

To a suspension of 1,10-phenanthroline-2,9-dicarbohydrazonamide 8 (0.50 g, $1.7 \mathrm{mmol})$ in dioxane (50 $\mathrm{mL}$ ) was added diphenylethane-1,2-dione (0.86 g, $4.1 \mathrm{mmol}, 2.4 \mathrm{eq})$. $\mathrm{Et}_{3} \mathrm{~N}$ (3 mL, $21.3 \mathrm{mmol}$ ) was added and the mixture was heated under reflux for 3 days. The solution was allowed to cool to room temperature and filtered and the remaining solid residue was washed with DCM $(50 \mathrm{~mL})$. The filtrate was evaporated and the solid was triturated with $\mathrm{Et}_{2} \mathrm{O}(100 \mathrm{~mL})$. The insoluble solid was filtered and washed with $\mathrm{Et}_{2} \mathrm{O}$ $(100 \mathrm{~mL})$ and allowed to dry in a vacuum oven $\left(40{ }^{\circ} \mathrm{C}\right)$ to afford the ligand $\mathbf{9 f}$ as a pale yellow solid $(0.65$ g, 59\%).

mp 270-273 ${ }^{\circ} \mathrm{C} ; \delta_{\mathrm{H}}\left(\mathrm{CDCl}_{3}\right)=7.41(\mathrm{~m}, 12 \mathrm{H}), 7.72(\mathrm{~d}, J=6.8 \mathrm{~Hz}, 4 \mathrm{H}), 7.91(\mathrm{~d}, J=6.8 \mathrm{~Hz}, 4 \mathrm{H}), 7.99$ (s, $2 \mathrm{H}), 8.52(\mathrm{~d}, J=8.3 \mathrm{~Hz}, 2 \mathrm{H}), 8.99(\mathrm{~d}, J=8.3 \mathrm{~Hz}, 2 \mathrm{H}) \mathrm{ppm} . \delta_{\mathrm{C}}\left(\mathrm{CDCl}_{3}\right)=123.2,127.7,128.6,128.7$, $129.6,129.9,130.4,135.5,137.4,138.3,146.5,152.9,156.1,156.4,160.8$ ppm. $\mathrm{C}_{84} \mathrm{H}_{52} \mathrm{~N}_{16}[\mathrm{M}+\mathrm{Na}]$ requires $m / z$ 1307.4453; (FTMS + c ESI) MS found $m / z 1307.4460 ; \mathrm{IR} v_{\max } / \mathrm{cm}^{-1}=3054,1581,1492$, 1444, 1379, 1361, 1215, 1181, 1147, 1102.

\section{Synthesis of 2,9-Bis(dimethyl-1,2,4-triazin-3-yl)-1,10-phenanthroline (BrPh-BTPhen, 9g)}

To a suspension of 1,10-phenanthroline-2,9-dicarbohydrazonamide 8 (0.26 g, $0.9 \mathrm{mmol})$ in THF (50 mL) was added 1,2-bis(4-bromophenyl)ethane-1,2-dione (0.75 g, $2.1 \mathrm{mmol}, 2.3 \mathrm{eq}) . \mathrm{Et}_{3} \mathrm{~N}$ (1.5 mL, 10.7 mmol) was added and the mixture was heated under reflux for 2 days. The solution was allowed to cool to room temperature and filtered and the remaining solid residue was washed with DCM (25 $\mathrm{mL})$. The filtrate was evaporated and the solid was triturated with $\mathrm{Et}_{2} \mathrm{O}(100 \mathrm{~mL})$. The insoluble solid was filtered and washed with $\mathrm{MeOH}(10 \mathrm{~mL})$ and $\mathrm{Et}_{2} \mathrm{O}(100 \mathrm{~mL})$ and allowed to dry in air to afford the ligand $\mathbf{9 g}$ as a pale brown solid $(0.51 \mathrm{~g}, 61 \%)$.

mp 312-315 ${ }^{\circ} \mathrm{C} ; \delta_{\mathrm{H}}\left(\mathrm{CDCl}_{3}\right)=7.54-7.68(\mathrm{~m}, 8 \mathrm{H}), 7.81-7.87(\mathrm{~m}, 8 \mathrm{H}), 7.99(\mathrm{~s}, 2 \mathrm{H}), 8.54(\mathrm{~d}, J=8.3 \mathrm{~Hz}$, 2H), $9.02(\mathrm{~d}, J=8.3 \mathrm{~Hz}, 2 \mathrm{H}) \mathrm{ppm} . \delta_{\mathrm{C}}\left(\mathrm{CDCl}_{3}\right)=123.1,124.9,126.2,127.8,129.9,131.1,132.2,132.3$, 134.4, 137.4, 146.5, 152.4, 154.7, 155.2, 160.7 ppm. $\mathrm{C}_{42} \mathrm{H}_{23} \mathrm{Br}_{4} \mathrm{~N}_{8}[\mathrm{MH}]^{+}$requires $m / z$ 954.8779; (FTMS $+\mathrm{p}$ ESI) MS found $m / z$ 954.8779; IR $v_{\max } / \mathrm{cm}^{-1}=1662,1587,1485,1380,1170,1109$. 


\section{General procedure for NMR titrations of C5-BTPhen, 9d.}

A $0.5 \mathrm{~mL}, 0.01 \mathrm{M}$ solution of C5-BTPhen $(\mathbf{9 d}, 5 \mu \mathrm{mol})$ in $\mathrm{CD}_{3} \mathrm{CN}$ was made up in an NMR tube. A 0.01 $\mathrm{M}$ solution of $\mathrm{Ln}\left(\mathrm{NO}_{3}\right)_{3} \cdot \mathrm{xH}_{2} \mathrm{O}$ was added in $25-50 \mu \mathrm{L}$ aliquots $\left(0.25-0.5 \mu \mathrm{mol}\right.$ per aliquot) and the ${ }^{1} \mathrm{H}$ NMR spectrum was recorded after each addition.

C5-BTPhen: $\delta_{\mathrm{H}}\left(\mathrm{CD}_{3} \mathrm{CN}\right)=0.94(\mathrm{t}, J=6.9 \mathrm{~Hz}, 6 \mathrm{H}), 0.95(\mathrm{t}, J=6.9 \mathrm{~Hz}, 6 \mathrm{H}) 1.46(\mathrm{~m}, 16 \mathrm{H}), 1.96$ (quint, $J=4.9 \mathrm{~Hz}, 8 \mathrm{H}), 3.00(\mathrm{t}, J=7.3 \mathrm{~Hz}, 4 \mathrm{H}), 3.10(\mathrm{t}, J=7.3 \mathrm{~Hz}, 4 \mathrm{H}), 8.09$ (s, 2H), $8.62(\mathrm{~d}, J=8.4 \mathrm{~Hz}), 8.81$ $(\mathrm{d}, J=8.4 \mathrm{~Hz}, 2 \mathrm{H}) \mathrm{ppm}$.

La(C5-BTPhen) $)_{2}\left(\mathbf{N O}_{3}\right)_{\mathbf{x}}: \delta_{\mathrm{H}}\left(\mathrm{CD}_{3} \mathrm{CN}\right)=0.62$ (quint, $\left.J=7.4 \mathrm{~Hz}, 4 \mathrm{H}\right), 0.70(\mathrm{t}, J=7.2 \mathrm{~Hz}, 6 \mathrm{H}), 0.80$ (quint, $J=7.4 \mathrm{~Hz}, 4 \mathrm{H}$ ), 0.89 (t, $J=7.2 \mathrm{~Hz}, 6 \mathrm{H}$ ), 0.93 (quint, $J=7.4 \mathrm{~Hz}, 4 \mathrm{H}$ ), $1.33(\mathrm{~m}, 8 \mathrm{H}$ ), 1.76 (quint, $J$ $=7.4 \mathrm{~Hz}, 4 \mathrm{H}), 2.39(\mathrm{t}, J=7.3 \mathrm{~Hz}, 4 \mathrm{H}), 2.74(\mathrm{t}, J=7.3 \mathrm{~Hz}, 4 \mathrm{H}), 8.49(\mathrm{~s}, 2 \mathrm{H}), 9.04(\mathrm{~d}, J=8.4 \mathrm{~Hz}, 2 \mathrm{H})$, $9.11(\mathrm{~d}, J=8.4 \mathrm{~Hz}, 2 \mathrm{H}) \mathrm{ppm}$.

Ln(C5-BTPhen) $)_{2}\left(\mathbf{N O}_{3}\right)_{\mathbf{x}}: \delta_{\mathrm{H}}\left(\mathrm{CD}_{3} \mathrm{CN}\right)=0.52$ (quint, $\left.J=7.4 \mathrm{~Hz}, 4 \mathrm{H}\right), 0.79(\mathrm{t}, J=7.2 \mathrm{~Hz}, 6 \mathrm{H}), 0.80-0.87$ (m, 10H), 1.06 (quint, $J=7.4 \mathrm{~Hz}, 4 \mathrm{H}), 1.30(\mathrm{~m}, 8 \mathrm{H}), 1.69$ (quint, $J=7.4 \mathrm{~Hz}, 4 \mathrm{H}), 2.28(\mathrm{t}, J=7.3 \mathrm{~Hz}, 4 \mathrm{H}$ ), $2.72(\mathrm{t}, J=7.3 \mathrm{~Hz}, 4 \mathrm{H}), 8.55(\mathrm{~s}, 2 \mathrm{H}), 8.96(\mathrm{~d}, J=8.4 \mathrm{~Hz}, 2 \mathrm{H}), 9.15(\mathrm{~d}, J=8.4 \mathrm{~Hz}, 2 \mathrm{H}) \mathrm{ppm}$.

\section{ACKNOWLEDGEMENTS}

The authors would like to acknowledge the EPSRC, M-Base and Acinet-I for financial support. Use of the Chemical Analysis Facility (CAF) at the University of Reading is gratefully acknowledged.

\section{REFERENCES}

1. F. W. Lewis, M. J. Hudson, and L. M. Harwood, Synlett, 2011, 2609.

2. M. J. Hudson, L. M. Harwood, F. W. Lewis, and D. M. Laventine, Inorg. Chem., 2012 (DOI: 10.1021/ic3008848).

3. M. J. Hudson, C. E. Boucher, D. Braekers, J. F. Desreux, M. G. B. Drew, M. R. S. Foreman, L. M. Harwood, C. Hill, C. Madic, F. Marken, and T. G. A. Youngs, New J. Chem., 2006, 30, 1171.

4. M. R. S. Foreman, M. J. Hudson, M. G. B. Drew, C. Hill, and C. Madic, Dalton Trans., 2006, 1645.

5. F. W. Lewis, L. M. Harwood, M. J. Hudson, M. G. B. Drew, J. F. Desreux, G. Vidick, N. Bouslimani, G. Modolo, A. Wilden, M. Sypula, T. H. Vu, and J. P. Simonin, J. Am. Chem. Soc., 2011, 133, 13093.

6. C. W. N. Cumper, R. F. A. Ginman, and A. I. Vogel, J. Chem. Soc., 1962, 1188.

7. G. Donnay, J. D. H. Donnay, and M. J. C. Harding, Acta. Cryst., 1965, 19, 688. 
8. P. Jones, G. B. Villeneuve, C. Fei, J. DeMarte, A. J. Haggarty, K. T. Nwe, D. A. Martin, A. M. Lebuis, J. M. Finkelstein, B. J. Gour-Salin, T. H. Chan, and B. R. Leyland-Jones, J. Med. Chem., 1998, 41, 3062 .

9. A. Zhang, E. Kuraoka, and M. J. Kumagai, Radioanalytical and Nuclear Chemistry, 2007, 274, 455.

10. S. Usuda, R. Liu, Y. Wei, Y. Xu, H. Yamazaki, and Y. Wakui, Ion Exchange, 2009, $21,35$. 